\title{
Pharmacist perceptions of new competency standards
} Pagamas MAITREEMIT, Petcharat PONGCHAROENSUK, Nattiya KAPOL, Edward P. ARMSTRONG. Accepted: 21-Jul-2008

\begin{abstract}
${ }^{*}$
Objective: To suggest revisions to the Thai pharmacy competency standards and determine the perceptions of Thai pharmacy practitioners and faculty about the proposed pharmacy competency standards.

Methods: The current competency standards were revised by brainstorming session with nine Thai pharmacy experts according to their perceptions of society's pharmacy needs. The revised standards were proposed and validated by 574 pharmacy practitioners and faculty members by using a written questionnaire. The respondents were classified based on their practice setting.

Results: The revision of pharmacy competency standard proposed the integration and addition to current competencies. Of 830 distributed questionnaires, 574 completed questionnaires were received $(69.2 \%$ response rate). The proposed new competency standards contained 7 domains and 46 competencies. The majority of the respondents were supportive of all 46 proposed competencies. The highest ranked domain was Domain 1 (Practice Pharmacy within Laws, Professional Standards, and Ethics). The second and third highest expectations of pharmacy graduates were Domain 4 (Provide pharmaceutical care) and Domain 3 (Communicate and disseminate knowledge effectively). Conclusion: The expectation for pharmacy graduates' competencies were high and respondents encouraged additional growth in multidisciplinary efforts to improve patient care.
\end{abstract}

Keywords: Professional Competence. Pharmacists. Education, Pharmacy. Thailand.

\section{PERCEPCIÓN DE LOS FARMACÉUTICOS SOBRE LOS NUEVOS ESTÁNDARES DE COMPETENCIA}

\section{RESUMEN}

Objetivo: Sugerir revisión a los estándares de competencia de farmacia tailandeses y determinar las percepciones de los facultativos farmacéuticos tailandeses sobre los estándares de competencia propuestos.

Métodos: Se revisaron los estándares de competencia actuales en una sesión de brainstorming con nueve expertos farmacéuticos tailandeses de acuerdo a sus percepciones de las necesidades de la sociedad sobre los farmacéuticos. Los estándares revisados fueron propuestos y validados por 574 farmacéuticos en ejercicio mediante un cuestionario escrito. Se clasificó a los respondentes según su lugar de ejercicio. Resultados: La revisión de los estándares actuales de competencia propuso la integración y adición de nuevas competencias. De los 830 cuestionarios distribuidos, se recibieron 574 cuestionarios completos $(69,2 \%$ tasa de respuesta). Los nuevos estándares de competencia propuestos contenían 7 dominios y 46 competencias. La mayoría de los respondentes apoyaron todas las 46 competencias. El dominio más valorado fue el Dominio 1 (Ejercicio de Farmacia en Leyes, Estándares profesionales, y Ética). Los segundo y tercero con más expectativas entre los graduados en farmacia fueron el Dominio 4 (Provisión de atención farmacéutica) y Dominio 3 (Comunicar y diseminar conocimientos efectivamente).

Conclusión: Las expectativas de las competencias de los graduados en farmacia fueron altas y los respondentes valoraban un crecimiento adicional de los esfuerzos multidisciplinarios para mejorar la atención al paciente.

Palabras clave: Competencia profesional. Farmacéuticos. Educación, Farmacia. Tailandia.

\section{INTRODUCTION}

Competencies are often used as an alternative to outcomes assessments in health care education, referring to a student's or practitioner's ability to perform actions in a real life setting. ${ }^{1}$ Competencies are important for students to accomplish before they

graduate, and for practitioners to maintain their

\footnotetext{
Pagamas MAITREEMIT. PhD. Faculty of Pharmacy, Silpakorn University, Nakhon Pathom, (Thailand). Petcharat PONGCHAROENSUK. PhD. Faculty of Pharmacy, Mahidol University, Bangkok, (Thailand). Nattiya KAPOL. PhD. Faculty of Pharmacy, Silpakorn University, Nakhon Pathom, (Thailand).

Edward P. ARMSTRONG. PharmD. College of Pharmacy, University of Arizona. Tucson, AZ (United States).
} 
ability in their professional practice. Competencies are not only used to control and maintain the quality of professional skills, but are also used as criteria to hire someone in a job. ${ }^{2}$ There are many techniques used to identify new competencies. Grussing suggested using multiple methods to identify competencies such as panel-generated competencies, validation by practitioner surveys, or validation by job analysis, etc. ${ }^{3}$

For health care programs, there are professional organizations that contribute to practitioner competencies in various healthcare settings. The Institute for International Medical Education (IIME) defined the "global minimum essential requirements" of undergraduate medical programs. These requirements represent a core competency for a medical school's curriculum for many countries. These competencies were developed by obtaining data from health policy experts and presidents or senior representatives of international organizations. Finally, the IIME defined a set of global minimum competencies that medical students should demonstrate before graduation. ${ }^{4}$ In comparison, for nursing programs, Lenburg, who had extensively worked with the New York Regents College Nursing Program and other educational organizations, developed the Competency Outcomes and Performance Assessment (COPA) model. $^{5}$

For pharmacy programs, the American Association of Colleges of Pharmacy (AACP) developed educational outcomes under the Center for the Advancement of Pharmaceutical Education (CAPE). Resources from the AACP Commission to Implement Change in Pharmaceutical Education, and other professional organizations' surveys were used to create the CAPE Educational Outcomes document. Similarly, both Australia and Canada have released new pharmacy competency standards.

In Thailand, the Thai Pharmacy Council established competency standards for their pharmacy licensure examination in 2002. The standards were developed by a group of Thai pharmacy experts and included an evaluation of standards used by other countries. The standards included eight domains: ${ }^{8}$ 1) Knowledge in pharmaceutical manufacturing processes and quality assurance; 2) Conduct a community health problem and drug needs assessment, drug selection and procurement of pharmaceutical products to serve patients appropriately; 3) Prepare an appropriate pharmaceutical product by extemporaneous preparation; 4) Conduct a basic health evaluation for appropriate patient counseling, including referral if necessary; 5) Provide rational drug use planning for each patient, including drug usage evaluation by focusing on patient involvement; 6) Follow up, prevent, and resolve drug related problems in a patient and a community, and report to appropriate organizations; 7) Provide up-to-date and reliable pharmaceutical and health product information to patients, communities, and health practitioners; and 8) Knowledge in pharmacy-related laws.
As the professional roles of pharmacists grow, and as health systems change, professional competencies should be reviewed and revised. ${ }^{9}$ Moreover, little is known about whether the current Thai competency standards meet the current needs of the Thai health care system. Hence, an assessment is needed to revise and validate the current Thai competency standards. Therefore, the purpose of this study was to suggest revisions to the Thai pharmacy competency standards and determine the perceptions of Thai pharmacy practitioners and faculty about the proposed pharmacy competency standards.

\section{METHODS}

\section{Study Design}

This study was a descriptive, cross-sectional study. An expert panel was utilized to revise and validate the Thai pharmacy competency statements. In addition, an attitudinal questionnaire was written and distributed to Thai pharmacists, including pharmacy faculty and current pharmacy practitioners to validate the revised standards. The final product from the study was a list of possible revisions to the current Thai pharmacy competency standards.

\section{Sample size}

The study population consisted of Thai pharmacy faculty members and current pharmacy practitioners. It was calculated that a sample size of 391 respondents would be needed to have a sample that was representative of all Thai pharmacists.

A stratified random sampling technique was used to identify pharmacists within six designated pharmacist practice settings. The six practice areas were classified as follows: ${ }^{10}$

1. Pharmacists who work in a related industry including pharmaceutical production, quality assurance, medication registration, etc. (Industry)

2. Pharmacists who work in marketing and selling of pharmaceuticals (Marketing)

3. Community pharmacists (Drug store)

4. Hospital pharmacists (Hospital)

5. Faculty members (Education)

6. Pharmacists who work in areas related to public health and consumer protection (FDA)

Based on the sample size calculation, the needed sample size was stratified by the six areas of practice. The needed sample sizes were $40,93,53$, 159, 24 and 24 responses, respectively.

Since a $50 \%$ response rate may be seen with a mail questionnaire, the minimum number of needed responses was doubled to determine the number of pharmacists invited to participate. Finally, 830 questionnaires were distributed and stratified by practice setting. 


\section{Development of new pharmacy guideline by brainstorming}

Thai pharmacy experts, including current practitioners, and members of the Board of Pharmacy were invited to participate in a professional "brainstorming" session. The meeting included nine experts and represented pharmacists from a public hospital, a private hospital, a provincial public health office, a drug company, industrial pharmaceutical plants, the community pharmacy association, the Thai Pharmacy Council, and the Thai Pharmaceutical Association.

During the brainstorming meeting, the researcher reviewed the importance of pharmacists' professional competencies. In addition, the current competency standards from several countries including the United States ${ }^{11}$, Canada ${ }^{7}$, and Australia ${ }^{6}$ were distributed to the panel of pharmacy experts.

The main questions asked of the expert panel were 1) whether the current Thai competency standards adequately addressed pharmacists' competencies and whether they appropriately addressed current societal needs; 2) what should be the required general and professional competencies for pharmacy graduates; and 3) what were the core competencies for pharmacy graduates? After reviewing the documents and discussing competency issues, the expert panel agreed that the existing Thai pharmacy standards needed to be revised.

\section{Questionnaire development}

The current competency standards, along with the data collected by the expert panel, were used to develop a questionnaire to measure the opinions of both pharmacy faculty members and pharmacy practitioners about the proposed pharmacy competency standards. The questionnaire was tested for face validity by three expert pharmacists.

The first draft of the questionnaire consolidated the expert panel's recommendation into 39 competencies and was pilot tested with 50 pharmacy practitioners and faculty members. The pilot sample included 19 public hospital pharmacists, three private hospital pharmacists, two community pharmacists, seven provincial public health pharmacists, and 19 faculty members who worked in Nakhon Pathom Province. Of the 50 participants, 64 percent were female, the average age was $33.96 \pm 3.97$ years old, and the highest academic degree received was the bachelor of science degree in pharmacy (56 percent). The average years of pharmacist experience was 10.94 \pm 6.6 years. In addition, $78 \%$ of participants had worked as a pharmacist in more than one practice setting. The reliability coefficient, Cronbach's alpha, was 0.9630 . Comments and suggestions from the pilot test were then used to clarify wording and to develop the final questionnaire. The final document included seven new domains and 46 competencies.

\section{Data collection}

The final questionnaire was divided into three parts as follows:
Part I contained questions about a respondent's demographic information. These questions included the respondent's gender, age, educational level, pharmacy school, area of practice, work location, and work experience.

Part II included results from the pilot test (seven new domains and 46 competencies) enabling respondents to provide their opinions regarding the proposed competency standards. The questions used a 5 point Likert scale ranging from strongly disagree (1) to strongly agree (5).

Part III was a section that requested additional information from the respondents with three questions. The first question asked the respondent to rank the three most important competency domains. The second question asked the respondents to express any additional opinions concerning any other competencies, and the third question provided respondents a place to state any recommendations regarding the Thai pharmacy curricula.

The questionnaire was distributed to pharmacists working in the six practice areas of Thai pharmacy practitioners and faculty members by either conventional mail or electronic mail. The selected names and contact information were randomly selected from several databases of pharmacists.

A cover letter, questionnaire, and self-addressed stamped return envelope was mailed to all pharmacists on June 5, 2006. For 44 marketing pharmacists, the questionnaires were sent via electronic mail. Three weeks after sending the first mail questionnaire, a follow-up questionnaire with a new cover letter and stamped return envelope was sent to non-respondents. The last completed questionnaire was received on August 25, 2006.

\section{New Pharmacy Competency Standard guideline}

Data from the returned questionnaires were recorded and summarized. Pharmacists' attitudes were analyzed to measure the respondents' perceptions of the proposed Thai pharmacy competency standards. In addition, the suggestions to modify the current Thai pharmacy competency standards were presented.

\section{Data analysis}

A reliability test was performed on the responses. Data were analyzed by SPSS program version 11.5 . A $p$-value $<0.05$ was used for all analyses to determine statistical significance. Descriptive statistics such as mean, standard deviation, standard error of the mean, coefficient of variation, and percentage was analyzed for demographic variables and attitudinal data. A One-Way Analysis of Variance (ANOVA) was used to analyze the difference in mean attitudinal scores across the six practice settings. If there was a significant difference among practice settings, a post hoc Scheffe test was conducted to determine which pairs of practice settings were different. Congruent analysis and consequence analysis were conducted to determine the rank of attitudinal scores across the six practice settings. In addition, Spearman's 
rho rank correlation was conducted to determine the rank order correlation between practice settings.

\section{RESULTS}

There were 830 questionnaires distributed to pharmacy faculty and pharmacy practitioners. Following the initial mailing of the cover letter and questionnaire, 389 (46.9\%) were returned. Nonrespondents received a second cover letter and questionnaire yielding an additional 185 responses, providing a total of 574 completed questionnaires (69.2\% response rate). There were fourteen (1.7\%) respondents that had changed jobs and now worked in a different area of pharmacy from that in the original mailing list.

Table 1 summarizes the demographic characteristics of the 574 respondents. The average age of the respondents was 37.67 $(S D=9.8)$ years old and 60 percent were female. The greatest number of respondents had obtained Bachelor of Science degrees. The results revealed that one third of respondent had obtained additional education after their initial pharmacy degree. Fortytwo percent of respondents had worked in pharmacy practice for less than 10 years. The mean years of pharmacy experience was $14.3(\mathrm{SD}=9.6)$.
Most pharmacists who had experience working in other practice areas had also worked with patients in either hospitals or community drug stores. It was noted that the gender, age, education level, workplace location, and years after graduation differed significant $(p<0.05)$ across the 6 practice settings.

\section{Respondents' expectation of pharmacy graduates}

The respondents were asked to rate their expectation of pharmacy graduates' competencies within seven new competency domains. The reliability coefficient of the questionnaire was 0.9631. The mean attitudinal scores on the seven competency domains across six practice settings are shown in Table 2. The rating score ranged from 1 (strongly disagree) to 5 (strongly agree). The results showed that the mean scores for all six practice settings ranged from 3.8 to 4.8 , with $4=$ agree and $5=$ strongly agree. Five of seven domains were rated higher than 4 for all six practice settings. The exceptions were Domain 2 (Care of primary health and drug use plans in the community) and Domain 5 (Produce and assure the quality of pharmaceutical products).

\begin{tabular}{|c|c|c|c|c|c|c|c|}
\hline Characteristics & $\begin{array}{c}\text { Industry } \\
\% \\
(\mathrm{n}=47)\end{array}$ & $\begin{array}{c}\text { Drug } \\
\text { store } \\
\% \\
(n=119)\end{array}$ & $\begin{array}{c}\text { Marketing } \\
\% \\
(\mathrm{n}=75)\end{array}$ & $\begin{array}{c}\text { Hospital } \\
\% \\
(n=252)\end{array}$ & $\begin{array}{c}\text { Education } \\
\% \\
(n=39)\end{array}$ & $\begin{array}{c}\text { FDA } \\
\% \\
(n=42)\end{array}$ & $\begin{array}{c}\text { Total } \\
\% \\
(n=574)\end{array}$ \\
\hline \multicolumn{8}{|l|}{ Gender } \\
\hline Male & 31.9 & 55.5 & 56.0 & 30.2 & 33.3 & 42.9 & 40.1 \\
\hline Female & 68.1 & 44.5 & 44.0 & 69.8 & 66.7 & 57.1 & 59.9 \\
\hline \multicolumn{8}{|c|}{ Age (Mean $=37.67$, S.D. $=9.81)$} \\
\hline $21-30$ years & 23.4 & 6.8 & 27.0 & 44.2 & 8.1 & 38.1 & 29.7 \\
\hline $31-40$ years & 23.4 & 23.9 & 55.4 & 41.0 & 51.4 & 28.6 & 37.6 \\
\hline $41-50$ years & 23.4 & 37.6 & 14.9 & 11.2 & 24.3 & 19.0 & 19.6 \\
\hline $51-60$ years & 19.1 & 27.4 & 2.7 & 3.6 & 13.5 & 14.3 & 11.1 \\
\hline $61-70$ years & 10.6 & 4.3 & 0.0 & 0.0 & 2.7 & 0.0 & 1.9 \\
\hline \multicolumn{8}{|l|}{ Highest education } \\
\hline Bachelor degree & 63.8 & 77.6 & 52.7 & 74.1 & 2.6 & 54.8 & 65.0 \\
\hline Master degree & 34.0 & 22.4 & 47.3 & 25.5 & 36.8 & 42.9 & 30.5 \\
\hline PhD degree & 2.1 & 0.0 & 0.0 & 0.4 & 60.5 & 2.4 & 4.6 \\
\hline \multicolumn{8}{|c|}{ Years after graduation $($ Mean $=14.26$, S.D. $=9.56)$} \\
\hline $0-10$ years & 31.1 & 8.8 & 37.8 & 63.6 & 24.3 & 43.9 & 42.4 \\
\hline $11-20$ years & 22.2 & 32.5 & 54.1 & 28.0 & 43.2 & 26.8 & 32.8 \\
\hline $21-30$ years & 26.7 & 37.7 & 8.1 & 6.4 & 24.3 & 29.3 & 17.5 \\
\hline $31-40$ years & 11.1 & 21.1 & 0.0 & 2.0 & 5.4 & 0.0 & 6.4 \\
\hline $41-50$ years & 8.9 & 0.0 & 0.0 & 0.0 & 2.7 & 0.0 & 0.9 \\
\hline \multicolumn{8}{|l|}{ Workplace } \\
\hline $\begin{array}{ll}\begin{array}{l}\text { Bangkok } \\
\text { surrounding }\end{array} & \text { and } \\
\end{array}$ & 85.1 & 52.6 & 65.3 & 17.6 & 31.6 & 46.3 & 39.8 \\
\hline Others & 14.9 & 47.4 & 34.7 & 82.3 & 68.4 & 53.7 & 60.2 \\
\hline \multicolumn{8}{|c|}{ Worked in more than 1 setting } \\
\hline No & 25.5 & 17.1 & 23.0 & 42.6 & 23.7 & 11.9 & 29.9 \\
\hline Yes & 74.5 & 82.9 & 77.0 & 57.4 & 76.3 & 88.1 & 70.1 \\
\hline
\end{tabular}

The Analysis of Variance (ANOVA) test was conducted to determine whether there were differences in mean scores across the six practice settings. Statistical test results showed that there were significant differences in mean attitudinal scores across the six practice settings in all seven competency domains ( $p$-value<0.05). Post hoc tests using the Scheffe method were conducted to determine which pairs of practice settings were significantly different.

The results demonstrate that pharmacists who worked in marketing and selling had attitude mean scores toward the pharmacy graduates' competencies that were different from that of 
hospital pharmacists for 6 domains. In addition, differences in attitudinal mean scores were found between hospital pharmacists and community pharmacists for Domain 3 (Communicate and disseminate knowledge effectively), Domain 4 (Provide pharmaceutical care), Domain 6 (Apply management skills in pharmacy), and Domain 7
(Retrieve and provide health and pharmaceutical product information). Differences in attitudinal scores for Domain 2 (Care of primary health and drug use plans in the community) were different between marketing pharmacists and community pharmacists.

\begin{tabular}{|c|c|c|c|c|c|c|}
\hline \multirow[b]{2}{*}{ Competency Domain } & \multicolumn{6}{|c|}{ Mean scores (SD) } \\
\hline & Industry & Marketing & $\begin{array}{l}\text { Drug } \\
\text { store }\end{array}$ & Hospital & Education & FDA \\
\hline $\begin{array}{l}\text { 1. Practice pharmacy under laws, } \\
\text { professional standards, and } \\
\text { ethics }\end{array}$ & $\begin{array}{c}4.64 \\
(0.34)\end{array}$ & $\begin{array}{c}4.54 \\
(0.51)\end{array}$ & $\begin{array}{c}4.73 \\
(0.38)\end{array}$ & $\begin{array}{c}4.77 \\
(0.38)\end{array}$ & $\begin{array}{c}4.61 \\
(0.49)\end{array}$ & $\begin{array}{l}4.67 \\
(0.39)\end{array}$ \\
\hline $\begin{array}{l}\text { 2. Care of primary health and drug } \\
\text { use plans in the community }\end{array}$ & $\begin{array}{c}4.04 \\
(0.51)\end{array}$ & $\begin{array}{l}3.89 \\
(0.68)\end{array}$ & $\begin{array}{c}4.18 \\
(0.50)\end{array}$ & $\begin{array}{c}4.13 \\
(0.52)\end{array}$ & $\begin{array}{l}4.06 \\
(0.57)\end{array}$ & $\begin{array}{c}4.09 \\
(0.51)\end{array}$ \\
\hline $\begin{array}{l}\text { 3. Communicate and disseminate } \\
\text { knowledge effectively }\end{array}$ & $\begin{array}{c}4.23 \\
(0.41) \\
\end{array}$ & $\begin{array}{l}4.20 \\
(0.61) \\
\end{array}$ & $\begin{array}{c}4.18 \\
(0.51) \\
\end{array}$ & $\begin{array}{c}4.42 \\
(0.49) \\
\end{array}$ & $\begin{array}{c}4.33 \\
(0.48) \\
\end{array}$ & $\begin{array}{c}4.25 \\
(0.39) \\
\end{array}$ \\
\hline 4. Provide pharmaceutical care & $\begin{array}{c}4.34 \\
(0.43) \\
\end{array}$ & $\begin{array}{c}4.15 \\
(0.66) \\
\end{array}$ & $\begin{array}{c}4.27 \\
(0.53) \\
\end{array}$ & $\begin{array}{c}4.52 \\
(0.49) \\
\end{array}$ & $\begin{array}{c}4.37 \\
(0.48) \\
\end{array}$ & $\begin{array}{c}4.36 \\
(0.47) \\
\end{array}$ \\
\hline $\begin{array}{l}\text { 5. Produce and assure the quality of } \\
\text { pharmaceutical products }\end{array}$ & $\begin{array}{c}4.04 \\
(0.50)\end{array}$ & $\begin{array}{l}3.77 \\
(0.81)\end{array}$ & $\begin{array}{l}3.84 \\
(0.65)\end{array}$ & $\begin{array}{l}4.06 \\
(0.63)\end{array}$ & $\begin{array}{l}4.01 \\
(0.58)\end{array}$ & $\begin{array}{c}4.10 \\
(0.62)\end{array}$ \\
\hline $\begin{array}{l}\text { 6. Apply management skills in } \\
\text { pharmacy }\end{array}$ & $\begin{array}{c}4.16 \\
(0.42) \\
\end{array}$ & $\begin{array}{c}4.07 \\
(0.64) \\
\end{array}$ & $\begin{array}{c}4.13 \\
(0.55) \\
\end{array}$ & $\begin{array}{c}4.36 \\
(0.52) \\
\end{array}$ & $\begin{array}{c}4.19 \\
(0.68) \\
\end{array}$ & $\begin{array}{c}4.27 \\
(0.47) \\
\end{array}$ \\
\hline $\begin{array}{l}\text { 7. Retrieve and provide health and } \\
\text { pharmaceutical } \\
\text { information }\end{array}$ & $\begin{array}{c}4.38 \\
(0.50)\end{array}$ & $\begin{array}{c}4.17 \\
(0.70)\end{array}$ & $\begin{array}{c}4.22 \\
(0.53)\end{array}$ & $\begin{array}{c}4.47 \\
(0.53)\end{array}$ & $\begin{array}{c}4.47 \\
(0.69)\end{array}$ & $\begin{array}{c}4.40 \\
(0.46)\end{array}$ \\
\hline
\end{tabular}

Although 11 differences were found in attitudinal mean scores across six practice settings, the determination of attitudinal score ranking was also valuable for this study. To compare the differences of attitudinal ranking across six practice settings, congruent and consequence analysis were performed across six practice settings. Descriptive statistics, including the mean score rating, standard deviation, standard error of mean, and the percent of coefficient of variation were noted for all competency statements in competency Domain 1 to 7. The competency statements for each domain were ranked based on the percent of coefficient variation $(\% \mathrm{CV})$ in each practice settings and for all respondents. The percent of $\mathrm{CV}$ relates the standard deviation of a set of values to its mean; it is the ratio of standard deviation to the mean and multiplied by 100 . Therefore, $\% \mathrm{CV}$ is useful for comparing two or more sets of data. The lowest $\% \mathrm{CV}$ has the highest rank. Additionally, the Spearman rho rank correlation test was conducted to indicate whether the rank order in practice settings was correlated.

The average rating scores of the respondents' expectation to all competency domains is shown in Table 3. Domain 1 competencies (Practice pharmacy under laws, professional standards, and ethics) had the highest rank from each group of pharmacists. Domain 1 had \% CV less than 10 percent. The second highest rank of all respondents was Domain 3 (Communicate and disseminate knowledge effectively). The third rank was Domain 4 (Provide pharmaceutical care). Domain 5 (Produce and assure the quality of pharmaceutical products) was ranked the lowest by 4 of 6 pharmacist groups. However, Domain 2 competencies (Care of primary health and drug use plans of community) were valued differently between pharmacist groups. The overall rank for this domain was the sixth, whereas pharmacists working in community drug stores rated this domain the second highest.

To confirm the ranking of the three highest ranked competency domains, respondents were asked to rank the three most important competency domains. The frequencies of each competency domain are summarized in Table 4.

Compared to respondents' expectation rating in Table 3, a similar ranking of the highest three domains was observed. The highest expectation of respondents was Domain 1 competencies (Practice pharmacy under laws, professional standards, and ethics). Domain 4 competencies (Provide pharmaceutical care) and Domain 3 competencies (Communicate and disseminate knowledge effectively) were ranked the second and third highest.

The respondents were asked to suggest additional competencies for pharmacy graduates in addition to competency Domains 1 to 7 . These suggestions are summarized in Table 5 . Almost $40 \%$ of respondents who provided a new competency suggested important attributes regarding pharmacists' character traits including leadership, human relation skills, respect for authority, moral sense, emotion control, creative thinking, patience, responsibility, etc. In addition, the application of holistic knowledge to pharmacy practice was the second most frequently reported competency by respondents. In addition, the application of modern technology, including computer software and hardware was also noted as an important expectation of pharmacy graduates' competency. 


\begin{tabular}{|c|c|c|c|c|c|c|c|c|c|}
\hline & & by FDA & - & $\sim$ & 寸 & $m$ & 10 & 0 & $\wedge$ \\
\hline & & $\begin{array}{l}\text { by } \\
\text { education }\end{array}$ & - & $m$ & $\sim$ & 0 & $\wedge$ & 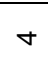 & $\omega$ \\
\hline & $\stackrel{\text { D }}{\frac{D}{x}}$ & $\begin{array}{l}\text { by } \\
\text { hospital }\end{array}$ & - & $m$ & $\sim$ & $\nabla$ & 10 & 0 & $\Lambda$ \\
\hline & 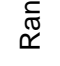 & $\begin{array}{l}\text { by } \\
\text { marketing }\end{array}$ & - & $\sim$ & 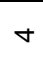 & 10 & $m$ & 0 & $\Lambda$ \\
\hline & & $\begin{array}{l}\text { by } \\
\text { drugstore }\end{array}$ & - & $m$ & $\nabla$ & 10 & 0 & $\sim$ & $\Lambda$ \\
\hline & & $\begin{array}{l}\text { by } \\
\text { Industry }\end{array}$ & - & $\sim$ & $m$ & 10 & $\nabla$ & $\wedge$ & 0 \\
\hline 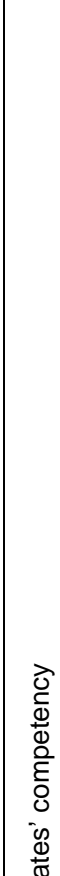 & & $\begin{array}{l}\frac{\pi}{d} \\
\frac{E}{d} \\
\frac{D}{\pi} \\
\tilde{\omega}\end{array}$ & 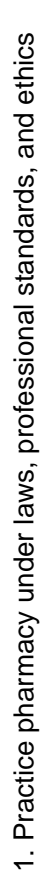 & 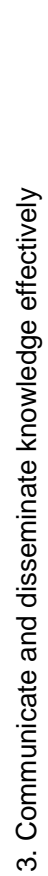 & 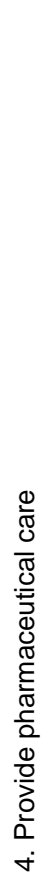 & 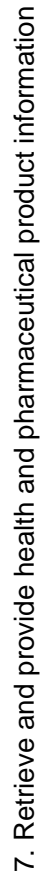 & 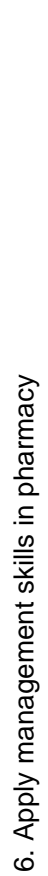 & 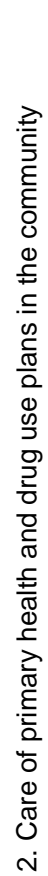 & 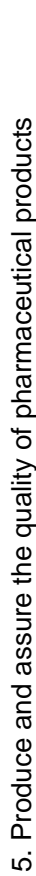 \\
\hline ত্ত & & $\begin{array}{l}\text { Ranking } \\
\text { by all }\end{array}$ & - & $\sim$ & $m$ & $\nabla$ & ما & 0 & $\Lambda$ \\
\hline $\begin{array}{l}\bar{\pi} \\
\frac{\pi}{2} \\
0\end{array}$ & & $\% \mathrm{CV}$ & $\underset{\infty}{N}$ & $\stackrel{\hat{R}}{\Gamma}$ & $\frac{\dot{v}}{\stackrel{N}{T}}$ & $\begin{array}{l}\mathscr{0} \\
\dot{m}\end{array}$ & 욤 & ָे & $\begin{array}{l}\hat{+} \\
\dot{\varphi}\end{array}$ \\
\hline $\begin{array}{l}\frac{\pi}{0} \\
\mathbb{0} \\
\frac{0}{x} \\
0\end{array}$ & & S.E. & Oे & O̊. & O̊. & Oั & Oे & O̊. & O̊. \\
\hline $\begin{array}{l}\frac{1}{0} \\
\frac{0}{0} \\
\frac{0}{0}\end{array}$ & & SD & 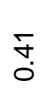 & Lొ & مొ & مُ & 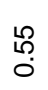 & 占 & @̊ \\
\hline $\begin{array}{l}m \\
\frac{0}{0} \\
\frac{0}{\sigma}\end{array}$ & & Mean & $\begin{array}{l}r \\
\dot{r}\end{array}$ & $\stackrel{\bar{m}}{\dot{*}}$ & $\stackrel{\substack{m \\
+}}{+}$ & $\stackrel{\hat{m}}{\dot{\sigma}}$ & 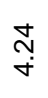 & $\underset{\dot{+}}{\stackrel{8}{+}}$ & 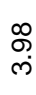 \\
\hline
\end{tabular}

\section{DISCUSSION}

The study findings revealed that most pharmacy practitioners agreed with the seven new domains and 46 competency statements. The mean scores were high (nearly 4.0 or higher for all domains). This implies that the respondents expected that all graduates should be able to perform these seven competencies and emphasizes their importance in serving society.

Competency Domain 1 (Practice pharmacy under laws, professional standards, and ethics) was the most highly valued competency from all study groups. It also showed that pharmacy practitioners were concerned about the value of ethical and legal issues. In accordance with current Thai practice environment, an honest pharmacist is expected by society.

The second and third highest expectations of pharmacy graduates were Domain 4 (Provide pharmaceutical care) and Domain 3 (Communicate and disseminate knowledge effectively). It was anticipated that communication and pharmaceutical care were highly valued and expected competencies. Professionally, it is important for pharmacists to have excellent patient-oriented skills. This finding is similar to the competencies needed in European countries. As demonstrated in the Thai responses, pharmaceutical care, communication, health promotion, and ethics were expected of new pharmacy graduates in Europe too. ${ }^{12}$

However, there were three competency statements in which the expectation was moderately less than other competency statements. These statements included preparation of sterile products and chemotherapeutic agents, and analyzing drugrelated problems for national policy planning. Pharmacists did not expect that all pharmacists would be able to prepare sterile products and chemotherapeutic agents because these roles would require special skills and facilities. Therefore, these competencies were rated lower by the respondents.

\section{Expectation of Competency Standards Based on Practice Settings}

From the mean scores of the seven new competency domains, it was apparent that four study groups (pharmacists from community drug stores, marketing, hospital, and FDA) had a lower expectation of the Domain 5 competency (Produce and assure the quality of pharmaceutical products). Although, the two remaining groups (pharmacists from industry, and education) did not rate the Domain 5 competency the lowest, their expectations were very low. A similar result was found in the United States. ${ }^{13}$ Porter reported that registered pharmacists in Oklahoma placed less emphasis in the area of compounding compared to dispensing or other areas of professional practice.

Another finding that should be considered was competency Domain 2 (Care of primary health and drug use plans of community). The majority of respondents had a low expectation of competency for Domain 2, except for pharmacists from 
community drug stores. This can be explained since community pharmacists work closely with the public and would be expected to highly value this competency. Thus, community pharmacists anticipate performing primary care in their professional roles more than pharmacists working in other practice settings.

A difference in the ranking of Domain 6 (Apply management skills in pharmacy) was found between the different practice areas of pharmacists. Pharmacists from marketing moderately expected that all graduates should be able to apply management skills. In contrast, educators ranked this characteristic extremely low. The reason for this difference may be that educators believe new graduates usually emphasize practice skills after graduation, rather than management skills. In contrast, management skills are usually applied by more senior pharmacists. However, marketing pharmacists expected that graduates should be able to apply management skills after graduation. Based on the skill set of marketing pharmacists, they are required to plan, organize, and manage themselves as a routine aspect of their jobs and they likely highly value basic management skills.

\begin{tabular}{|c|c|c|c|c|c|}
\hline Domain no. & Competency domains & First & Second & Third & Rank \\
\hline 1 & $\begin{array}{l}\text { Practice pharmacy under laws, professional } \\
\text { standards, and ethics }\end{array}$ & 356 & 56 & 43 & 1 \\
\hline 4 & Provide pharmaceutical care & 99 & 145 & 79 & 2 \\
\hline 3 & $\begin{array}{l}\text { Communicate and disseminate knowledge } \\
\text { effectively }\end{array}$ & 45 & 151 & 138 & 3 \\
\hline 2 & $\begin{array}{l}\text { Care of primary health and drug use plans } \\
\text { of community }\end{array}$ & 26 & 101 & 66 & 4 \\
\hline 7 & $\begin{array}{l}\text { Retrieve and provide health and } \\
\text { pharmaceutical product information }\end{array}$ & 11 & 46 & 100 & 5 \\
\hline 6 & Apply management skills in pharmacy & 13 & 29 & 92 & 6 \\
\hline 5 & $\begin{array}{l}\text { Produce and assure the quality of } \\
\text { pharmaceutical products }\end{array}$ & 8 & 31 & 39 & 7 \\
\hline
\end{tabular}

\begin{tabular}{|l|c|c|}
\hline \multicolumn{1}{|c|}{ Table 5: Respondents' expectation to other competencies of pharmacy graduates } \\
\hline \multicolumn{1}{|c|}{ Ability } & No. of responses & $\%$ \\
\hline Perform good personality and traits & 60 & 39.2 \\
\hline Apply multidiscipline to pharmacy practice & 23 & 15.0 \\
\hline Apply modern technology to work practice & 17 & 11.1 \\
\hline Apply marketing concept to practice & 8 & 5.2 \\
\hline Apply knowledge in Thai traditional medicine to practice & 7 & 4.6 \\
\hline Improve work quality & 6 & 3.9 \\
\hline Discuss with a physician about medicine & 4 & 2.6 \\
\hline Participate societal activities & 4 & 2.6 \\
\hline Protect consumers from health risk factors & 4 & 2.6 \\
\hline Others & 20 & 13.1 \\
\hline Total & 153 & 100.0 \\
\hline
\end{tabular}

Overall, the competency ranking by different pharmacist groups was affected by many factors, including practice setting. Since professional work experience influences the perception of required competencies, respondents appear to have highly valued competency focused toward their own professional needs.

\section{CONCLUSIONS}

Respondents' expectation for pharmacy graduates' competencies were high and respondents encouraged additional growth in multidisciplinary efforts to improve patient care. To meet these expanded societal expectations, several important pharmacy-related organizations and schools of pharmacy will need to adjust their roles and enhance collaboration with each other.

\section{ACKNOWLEDGEMENTS}

The authors acknowledge the Faculty of Pharmacy, Silpakorn University for funding on this research. In addition, we would like to recognize pharmacy experts and all pharmacists who provide valuable information for this study.

\section{CONFLICT OF INTEREST}

The authors have no conflicts of interest in this study. This study has been funded by Faculty of Pharmacy, Silpakorn University.

\section{References}

1. McConnell EA. Competence vs. competency. Nurs Manag. 2001;32(5):14.

2. Dobbert DJ. Experiences with and assessment of competency-based curriculum in disciplines outside of pharmacy. Am J Pharm Educ. 1975;39(5): 560-566.

3. Grussing PG. Curricular design: competency perspective. Am J Pharm Educ. 1987;51(4):414-419. 
4. Core committee, Institute for International Medical Education. Global minimum essential requirements in medical education. Med Teach. 2002;24(2):130-135.

5. Lenburg CB. The framework, concepts and methods of the competency outcomes and performance assessment (COPA) model. Online J Issues Nurs. 1999; 4.

6. Competency Standards for Pharmacists in Australia 2003, Pharmaceutical Society of Australia. (Accessed on August 16, 2006, at http://www.psa.org.au/site.php?id=643\& output =print)

7. Professional Competencies for Canadian Pharmacists at Entry to Practice, 1997. National Association of Pharmacy Regulatory Authorities, Canada. (Accessed on August 20, 2004, at http://www.napra.ca/pharmacists/becoming/competencies.pdf)

8. Standard criteria for pharmacy practitioners 2002. Thai Pharmacy Council. (Access on August 20, 2004, at http://www.pharmacycouncil.org/html/center_exam. html)

9. McCombs JS, Nichol MB, Johnson KA, Hay JW, Ebin VJ, Lawrence GD, Schneider JS. Is pharmacy's vision of the future too narrow? Am J Health Syst Pharm. Jun 1 1995;52(11):1208-1214.

10. Jantarasakul J. "Evolution of Pharmacy Profession" in The 9th year of The Pharmacy Council. Bangkok: Integrated Publication, Co., Ltd.; 2003:90.

11. Accreditation Standards and Guidelines for The Professional Program in Pharmacy Leading to The Doctor of Pharmacy Degree. Chicago, Illinois: Accreditation Council for Pharmacy Education, 2006. (Accessed on Jul 13, 2006, at http:// www.acpe-accredit.org/pdf/ACPE_Revised_PharmD_Standards_Adopted_Jan152006.pdf)

12. van Mil JWF, Schulz M, Tromp TFJ. Pharmaceutical care, European developments in concepts, implementation, teaching, and research: a review. Pharm World Sci. 2004;26:303-311.

13. Porter ME. Survey of pharmacists' attitudes toward formal academic pharmacy education. Am J Pharm Educ. 1978;42(8):264-269. 